significantly higher cane yield compared to other treatments (Table 2). The increased cane yield under the paired rows was attributed to increase in planting density and better distribution of crop plants due to which the crop enjoyed favorable environment for its growth which resulted in higher number of millable canes under paired rows resulting into increased cane yield. It indicated that by changing the planting pattern from single to paired rows, on an average, additional cane yield of 6.8 and $7.5 \mathrm{t} / \mathrm{ha}$ was obtained over 90 and $60 \mathrm{~cm}$ row spacing, respectively. The cane yield under the planting densities of 37,500 (spaced at 90 $\mathrm{cm}$ ) and 56,250 (spaced at $60 \mathrm{~cm}$ ) three budded sets/ ha was at par indicating that the planting density at these rates was not sufficient to exert their differential influence on the cane yield. The cane quality, however remained unaffected by the planting density/geometry (Table 3). These results are in line with the earlier studies conducted by Phogat et al. (1989), Singh et al. (1994) and Yadav et al. (1997) who also reported higher cane yield under paired row planting.

The results concluded that paired row $(60: 30 \mathrm{~cm})$ planting by using 75,000 three budded setts/ha is better over planting in single rows, either at $90 \mathrm{~cm}$ using 37,500 three budded setts/ha or at $60 \mathrm{~cm}$ using 56,250 three budded setts/ha.

Our results concluded that under late sown conditions, planting in furrows, covering the setts with $2 \mathrm{~cm}$ soil layer f.b. irrigation and blind hoeing and planted in paired rows (using 75,000 three budded setts/ ha), was the most beneficial method of planting.

\section{REFERENCES}

Anonymous (1998) Annual report (1997-98). Punjab Agricultural University Sugarcane Research Station, Jalandhar. pp 8.

Bajelan, B. and Nazir, N.S. (1993). Effect of fertility variation and planting pattern on growth, yield and quality of sugarcane. Intl. J. Tropical Agri., 11 : 249-254.

Clements, H.F. (1980). Sugarcane crop logging and crop control : Principles and practices. Pituman Publishing Co., London. pp. 133.

Dhawan, A.K., Sahtiya, H.L. and Dendsay, J.P.S. (1997). Low germination of sugarcane setts in Indian sub-tropics : Constraints and their Management. Indian J. Sugarcane Tech., 12: 17-21.

Phogat, S.S., Verma, S.S. and Kumar, S. (1989). Effect of row spacing and nitrogen on late planted sugarcane. Indian J. Agron., $34: 257-258$.

Prasad, S.R., Motivale, M.P. and Singh, A.B. (1979). Effect of plant population and moisture regime on yield and quality of timely and late planted sugarcane in North-India. Indian J. Agric. Sci., 49 : 252-265.

Singh, D., Jain, D.L. and Singh, D. (1994). Effect of $K$ in combination with planting pattern on autumn sugarcane. Indian $J$. Agric. Sci., 64 : 397-399.

Srivastava, S.N.L., Ranwa, R.S. and Kumar, S. (1997). Influence of planting geometry and nitrogen levels on sugarcane and sugar productivity. Indian J. Sugarcane Tech., 12: 17-21.

Yadav, D.V. and Singh, G.B. (1997). Appropriate agro-techniques to enhance sugar productivity. Indian J. Sugarcane Tech., 12: 116 .

Yadav, R.L., Singh, R.V., Singh, R. and Srivastava, V.K. (1997). Effect of planting geometry and fertilizer $N$ on nitrate leaching, NUE and sugarcane yield. Tropical Agri., 74 : 115-120.

\title{
MEETING/ CONFERENCES/ SYMPOSIA/ WORKSHOP/ SEMINARS
}

September 3-4, 2002

The 8th Asia International Sugar Conference 2002

Contact : Yuh Tyan

Nusa Dua Beach Hotel \& Spa, Bali, Indonesia

Phone : +65-68355135; Fax : +65-67335087, 67364312

e-mail : yuhtyan.lew@ibcasia.com.sg

October 24-26, 2002

International Conference and Exhibition on Sugar Mill Cogeneration

Contact : Outreach Cell

Winrock International India

7, Poorvi Marg, Vasant Vihar, New Delhi - 110 057, India

Tel. : 91-11-614-2965; Fax : 91-11-614-6004

e-mail : winrock@vsnl.com

website : www.winrockindia.org

www.renewingindia.org
January 16-21, 2005

XXV ISSCT Congress

Contact : Secretary/Treasurer

Mauricio Cobarrus, Vice-President

Cengicana, 6a, Calle 6-38

Zona-9, Edificio Tivoli

Officiana 6, Sotano

Guatemala City

e-mail : cengican@concyt.gob.gt centro@cengicana.org

Tel. : (502)331-3068

Fax : (502)334-0635 